\title{
Establishment of in vitro aseptic culture of Philodendron xanadu Croat $^{1}$
}

\author{
Establecimiento del cultivo aséptico in vitro de filodendro xanadu
}

\author{
Moises Lara-Ascencio ${ }^{2}$, María Andrade-Rodríguez ${ }^{2 *}$, Dagoberto Guillén-Sánchez ${ }^{2}$, Héctor Sotelo-Nava ${ }^{2}$ and \\ Oscar Gabriel Villegas-Torres ${ }^{2}$
}

\begin{abstract}
The philodendron is a plant with a high sales price; however, in Mexico there is not enough plant material available for the producers of this ornamental. Therefore, the objective of this research was to establish an in vitro aseptic culture of philodendron; for this, the effect of fungicides and bactericides applied from the transplantation of mother plants to the production and harvest of explants (axillary shoots) for in vitro establishment was evaluated. Two experiments were carried out using MS (MURASHIGE; SKOOG, 1962) culture medium; in the second, silver nanoparticles (AgNPs) were added to the culture medium. Both experiments were established in a completely randomized experimental design. It was observed that with the joint action of the sanitizing products in the treatment of mother plants and in the disinfection process, as well as the addition of AgNPs to the culture medium, it was possible to establish an aseptic culture of philodendron. Results show that $2 \mathrm{~g} \mathrm{~L}^{-1}$ of Agry-Gent Plus $5000^{\circledR}$ plus $2 \mathrm{~g} \mathrm{~L}^{-1}$ of Prozycar ${ }^{\circledR}$ in the treatment of mother plants was the one generated the highest percentage of aseptic explants (25.71\%) in the first in vitro establishment, while, in the second experiment, the same products plus the addition of AgNPs to the culture medium for seven days generated $100 \%$ aseptic explants. The contaminants identified were yeasts, Aspergillus sp. and Penicillium sp.
\end{abstract}

Key words: Philodendron. Sanitizers. Vitro pathogens. Asepsis. Micropropagation.

\begin{abstract}
RESUMO - O filodendro é uma planta com alto preço de venda, entretanto, no México não há material vegetal suficiente disponível para os produtores desta ornamental. Portanto, o objetivo desta pesquisa foi estabelecer uma cultura in vitro asséptica de filodendro, para isso, avaliou-se o efeito de fungicidas e bactericidas aplicados desde o transplante de plantas-mãe até a produção e colheita de explantes (brotos axilares) para estabelecimento in vitro. Dois experimentos foram realizados usando meio de cultura MS, no segundo, nanopartículas de prata (AgNPs) foram adicionadas ao meio de cultura. Ambos os experimentos foram estabelecidos em um delineamento experimental inteiramente casualizado. Observou-se que com a ação conjunta dos saneantes no tratamento das plantas-mãe e no processo de desinfecção, bem como a adição de AgNPs ao meio de cultura, foi possível estabelecer uma cultura asséptica do filodendro. Os resultados indicaram que $2 \mathrm{~g} \mathrm{~L}^{-1}$ de Agry-Gent Plus $5000 \AA$ mais $2 \mathrm{~g} \mathrm{~L}^{-1}$ de Prozycar ${ }^{\circledR}$ no tratamento de plantas-mãe foi o que gerou a maior porcentagem de explantes assépticos $(25,71 \%)$ no primeiro estabelecimento in vitro, enquanto, no segundo experimento, os mesmos produtos mais a adição de AgNPs ao meio de cultura por sete dias geraram explantes $100 \%$ assépticos. Os contaminantes identificados foram leveduras, Aspergillus sp. e Penicillium sp.
\end{abstract}

Palavras-chave: Filodendro. Sanitizantes. Patógenos vitro. Assepsia. Micropropagação.

DOI: $10.5935 / 1806-6690.20210024$

Editor-in-Chief: Prof. Bruno Lessa - bruno.ftlessa@univasf.edu.br

*Author for correspondence

Received for publication on 28/11/2019; approved on 23/11/2020

${ }^{1}$ Investigation that is part of the thesis of the first author, Doctorado en Ciencias Agropecuarias y Desarrollo Rural, Facultad de Ciencias Agropecuarias, Universidad Autónoma del Estado de Morelos, Cuernavaca, Morelos, México

${ }^{2}$ Posgrado en Ciencias Agropecuarias y Desarrollo Rural, Facultad de Ciencias Agropecuarias, Universidad Autónoma del Estado de Morelos (UAEM), Cuernavaca, Morelos, México. moises.crops@hotmail.com (ORCID ID 0000-0002-8247-3842), maria.andrade@uaem.mx (ORCID ID 0000-0003-0757-742X), dagoguillen@yahoo.com (ORCID ID 0000-0001-5958-4969), hector.sotelo@uaem.mx (ORCID ID 0000-0002-0926-9191), voscar66@yahoo.com.m (ORCID ID 0000-0001-9885-3906) 


\section{INTRODUCTION}

Philodendron is the second largest genus of the family Araceae, with 480 exclusively Neotropical species (BOYCE; CROAT, 2014). The morphological variability that exists among the different species, the recently developed cultivars, and their growth habit makes philodendron cultivars suitable for use as ornamental desk plants, hanging baskets, totems, or floor plants (McCONNELL et al., 2003). In Mexico, seven endemic species have been recorded distributed in the tropical zones of the states of Veracruz, Chiapas and Oaxaca (ACEBEY; KRÖMER, 2008).

Ornamental plant production in Morelos is estimated at 3000 ha with a production value of US\$61,538 per ha/ year; philodendron is among the most important of these species (RAMÍREZ-ROJAS et al., 2016); the sales price varies from 0.44 to 0.56 dollars at the seedling stage in 72,98 and 128 cavity containers, while in pots it ranges from 1.8 to 6.2 dollars, depending on the points of sale and size of the plant (AKIKO, 2020; FLORAMUNDO, 2020).

In vitro culture is an asexual reproduction technique under aseptic conditions, which exploits the ability of each plant cell to generate genetically identical individuals (clones) (ROUT; MOHAPATRA; JAIN, 2006). Ornamental plant production has used this technique to multiply plants with a high degree of uniformity and health (RAMÍREZ-ROJAS et al., 2016). Most commercialized plants of the genus Philodendron are propagated by in vitro tissue culture (McCONNELL et al., 2003).

To initiate in vitro cultures, there is a serious problem with contaminants, as they compete advantageously with plants for the nutrients in the culture medium and end up killing the tissues (AZOFEIFA-BOLAÑOS et al., 2019). Therefore, it is necessary to develop efficient explant disinfection protocols that eliminate exogenous microorganisms.

In this sense, the treatment of mother plants with fungicides and bactericides before in vitro establishment and during the disinfection process of philodendron explants is effective in achieving asepsis, since pathogens hosted in the plant organs are prevented and eliminated. Chen et al. (2012), established the aseptic culture of three Philodendron cultivars by spraying the mother plants with Ridomil $\mathrm{MZ}^{\circledR}$ and Mancozeb ${ }^{\circledR}$ one week prior to explant excision and disinfested them with $70 \%$ ethanol for one min followed by a $1 \%(\mathrm{v} / \mathrm{v})$ sodium hypochlorite solution for $20 \mathrm{~min}$. Also, Mariani et al. (2011), achieved the aseptic establishment of Aglaonema sp. by soaking the explants in Antracol $^{\circledR}$ for $30 \mathrm{~min}$, then in $70 \%$ ethanol for two min and finally in 20 and $50 \%$ Clorox $^{\circledR}$ for ten min.

Recently, the application of silver nanoparticles (AgNPs) in plant tissue culture has increased due to their ability to eliminate microorganisms that affect in vitro cultures (VILLAMIZAR-GALLARDO; CRUZ; ORTÍZRODRÍGUEZ, 2016). Explant disinfection protocols during in vitro establishment with AgNPs produce good aseptic results (ABDI; SALEHI; KHOSH-KHUI, 2008; MORADPOUR; AZIZ; ABDULLAH, 2016).

Given the economic importance of philodendron and the need to have enough micropropagated material for the producers of this plant, the objective of the research was to generate a protocol for in vitro aseptic culture establishment of Philodendron xanadu to initiate mass propagation and meet the demand for this species.

\section{MATERIAL AND METHODS}

\section{Treatment of mother plants with sanitizers}

Philodendron seedlings of $8 \mathrm{~cm}$ in height, obtained from in vitro culture and acclimatized, were established in 6-inch pots containing tezontle (red igneous rock of volcanic origin) with particle size of $5 \mathrm{~mm}$ as substrate. After transplanting, the plants were sprayed with sanitizing products (Table 1). The plants were grown under greenhouse conditions. Sprays were applied every fourteen days for 11 months, together with fertilization; nutrition was applied in water according to Steiner's formulation (1984), and $1 \mathrm{~mL} \mathrm{~L}^{-1}$ of ANIBAC $580^{\circledR}$ (quaternary ammonium) was added to it to prevent the presence of pathogens in the substrate. Ten plants were used per treatment.

Murashige and Skoog (1962) culture medium supplemented with $30 \mathrm{~g} \mathrm{~L}^{-1}$ of sucrose, $80 \mathrm{mg} \mathrm{L}^{-1}$ of adenine sulfate, thiamine, glycine, pyridoxine, nicotinic acid $\left(0.5 \mathrm{mg} \mathrm{L}^{-1}\right)$, and inositol $\left(100 \mathrm{mg} \mathrm{L}^{-1}\right)$ was used; $\mathrm{pH}$ was adjusted to 5.7 and $7.5 \mathrm{~g} \mathrm{~L}^{-1}$ of Merck $^{\circledR}$ agar were used as gelling agent. Also, $100-\mathrm{mL}$ flasks with $20 \mathrm{~mL}$ of culture medium were used. The culture medium was sterilized for $18 \mathrm{~min}$ in a vertical autoclave at $1.2 \mathrm{~kg} \mathrm{~cm}^{-2}$ and $120^{\circ} \mathrm{C}$.

For in vitro establishment, plants treated with the sanitizers and grown for 185 days after transplanting were used. Axillary shoots of 3 to $5 \mathrm{~cm}$ were taken and placed separately according to treatment (Table 1). Leaves and petioles were removed from each shoot and washed with plenty of soap and water; subsequently, the shoots were submerged for $30 \mathrm{~min}$ in a solution prepared with the fungicide Tokat ${ }^{\circledR}\left(1 \mathrm{~mL} \mathrm{~L}^{-1}\right)$ and the bactericide Agry-Gent Plus $5000^{\circledR}\left(2 \mathrm{~g} \mathrm{~L}^{-1}\right)$. After $30 \mathrm{~min}$, under aseptic conditions, the explants were immersed in $70 \%$ ethanol for $1 \mathrm{~min}$, the alcohol was removed and a $0.16 \%$ sodium hypochlorite $(\mathrm{NaOCl})$ solution was added; the explants in the solution were shaken for $5 \mathrm{~min}$ and then rinsed three times with sterile distilled water. The explants were dissected by removing leaves until the apices were $3 \mathrm{~mm}$ at the base and 
Table 1 - Composition of treatments for the aseptic culture establishment of Philodendron xanadu explants

\begin{tabular}{|c|c|c|c|c|}
\hline Treatment & Treatment key & Bactericide $\left(\mathrm{g} \mathrm{L}^{-1}\right)$ & & Fungicide $\left(\mathrm{g} \mathrm{L}^{-1}\right)$ \\
\hline 1 & $\mathrm{C} 1+\mathrm{P}$ & Cuprimicin $100 \AA(2)$ & + & Prozycar $\AA(2)$ \\
\hline 2 & $\mathrm{C} 1+\mathrm{T}$ & Cuprimicin $100 \AA(2)$ & + & Tokat® (1) \\
\hline 3 & $\mathrm{AG}+\mathrm{P}$ & Agry-Gent Plus ${ }^{\circledR}(2)$ & + & Prozycar ${ }^{\circledR}(2)$ \\
\hline 4 & $\mathrm{AG}+\mathrm{T}$ & Agry-Gent Plus ${ }^{\circledR}(2)$ & + & Tokat® (1) \\
\hline 5 & $\mathrm{C} 5+\mathrm{P}$ & Cuprimcin $500 \circledR$ (3) & + & Prozycar ${ }^{\circledR}(2)$ \\
\hline 6 & $\mathrm{C} 5+\mathrm{T}$ & Cuprimcin 500® (3) & + & Tokat® (1) \\
\hline 7 & $\mathrm{AGP}+\mathrm{P}$ & Agry-Gent Plus 5000® (2) & + & Prozycar ${ }^{\circledR}(2)$ \\
\hline 8 & $\mathrm{AGP}+\mathrm{T}$ & Agry-Gent Plus 5000® (2) & + & Tokat@ (1) \\
\hline
\end{tabular}

in height; five explants were established per culture flask and incubated at $28 \pm 2{ }^{\circ} \mathrm{C}$, with a photoperiod of $16 \mathrm{~h}$ light and $8 \mathrm{~h}$ dark, and a light intensity of $32 \mu \mathrm{mol} \cdot \mathrm{m}^{-2} \cdot \mathrm{s}^{-1}$.

Eight treatments (Table 1) with seven replicates were studied in a completely randomized experimental design. The experimental unit was a $100-\mathrm{mL}$ flask with $20 \mathrm{~mL}$ of culture medium and five explants per flask.

Seven days after in vitro establishment, the asepsis of the culture was evaluated (explants free of bacteria and fungi) and the percentage of contamination was determined, as well as the type of contaminant.

\section{Treatment of mother plants with sanitizers and use of silver nanoparticles (AgNPs)}

Murashige and Skoog (1962) culture medium was prepared in liquid state, supplemented with $30 \mathrm{~g} \mathrm{~L}^{-1}$ of sucrose, $80 \mathrm{mg} \mathrm{L}^{-1}$ of adenine sulfate, thiamine, glycine, pyridoxine, nicotinic acid $\left(0.5 \mathrm{mg} \mathrm{L}^{-1}\right)$ and inositol (100 $\mathrm{mg} \mathrm{L}^{-1}$ ); $\mathrm{pH}$ was adjusted to 5.7. The culture medium was sterilized for $18 \mathrm{~min}$ in a vertical autoclave at $1.2 \mathrm{~kg} \mathrm{~cm}^{-2}$ and $120^{\circ} \mathrm{C}$. AgNPs were added to the whole medium in doses of $200 \mathrm{mg} \mathrm{L}^{-1}$ when it had a temperature of approximately $38^{\circ} \mathrm{C}$. Sterile 100 -mL flasks were used and $20 \mathrm{~mL}$ of liquid culture medium were added to each one.

Separately, the same medium described above was prepared, to which $7.5 \mathrm{~g} \mathrm{~L}^{-1}$ of Merck ${ }^{\circledR}$ agar were added to solidify it; the medium was sterilized in the same way as the previous medium. Sterile 100 -mL flasks were used and $20 \mathrm{~mL}$ of culture medium were added to each one.

For this second explant disinfection establishment, the mother plants treated with the sanitizing agents indicated in Table 1 were used, 330 days after transplanting. The explant preparation and disinfection process was the same as in the previous experiment.

After disinfection, the explants were established in liquid culture medium with AgNPs and placed on an orbital shaker for seven days. Subsequently, the aseptic explants were subcultured by transferring them to semisolid culture medium. The explants were incubated at $28 \pm 2{ }^{\circ} \mathrm{C}$, with a photoperiod of $16 \mathrm{~h}$ light and $8 \mathrm{~h}$ dark, and a light intensity of $32 \mu \mathrm{mol} \cdot \mathrm{m}^{-2} \cdot \mathrm{s}^{-1}$.

Eight treatments (Table 1) with five replicates were studied in a completely randomized experimental design. The experimental unit was a $100-\mathrm{mL}$ flask with $20 \mathrm{~mL}$ of culture medium and five explants per flask.

Explant asepsis was evaluated seven days after subculturing in semisolid medium (explants free of bacteria and fungi), and the percentage of contamination was assessed, as well as the type of contaminant.

The data from the two experiments were studied using analysis of variance (ANOVA) and the comparison of means test (LSD) was performed with the SAS System version 9.0 statistical package. The variables evaluated were transformed with the square root function prior to statistical analysis.

\section{Identification of contaminants}

To identify the contaminants that grew during the establishment of the aseptic philodendron culture, a sample of each contaminated explant was taken with a sterile dissection needle; 12 fungal isolates and one bacterial isolate were obtained. Each sample was placed in a Petri dish with potato dextrose agar (PDA) and incubated at room temperature for 72 hours. The contaminants were reisolated again on PDA to obtain pure cultures. The fungal mycelium was mounted on slides with lactophenol blue. The morphological structures of the contaminant were observed with a compound microscope at 40x.

The pure isolate visually identified as bacterial was inoculated on PDA medium with $2 \mathrm{~mL} \mathrm{~L}^{-1}$ of $25 \%$ lactic acid and culture medium with eosin methylene blue (EMB) agar and incubated for 24 to $48 \mathrm{~h}$. Isolations were also made in potato slices in humidity chambers using paper towels, water and sterile Petri dishes; a scratch was made with a sterilized dissection needle and inoculated with the pure culture. 


\section{RESULT AND DISCUSSION}

\section{Treatment of mother plants with sanitizers}

Both the analysis of variance and the comparison of means test indicated that there were no differences in asepsis due to the effect of the treatments of the mother plants with sanitizing products. However, it is important to note that the presence of bacteria was not observed, indicating that the bactericides used in the treatments had good efficiency. In most cases, bacteria are the most difficult microorganisms to eliminate during the process of disinfection and in vitro establishment, and are the cause of the highest percentage of contamination in plant tissue culture (CAPÓ, 2000; RAMÍREZ-ROJAS et al., 2016; SÁNCHEZ et al., 2015), indicating that the treatments used in this research produced good results for the elimination of bactericides.

In the eight treatments with sanitizing products, fungal and yeast growth was observed along with the explants established in vitro. The treatment with Agry-Gent Plus $5000^{\circledR}$ plus Prozycar ${ }^{\circledR}$ applied to the mother plants during their growth was the combination that generated the highest explant asepsis $(25.71 \%)$; this can be attributed to the synergistic effect of the bactericide Agry-Gent Plus $5000^{\circledR}$ and the fungicide Prozycar ${ }^{\circledR}$ in reducing the amount of contaminants, since the combination of this bactericide with the fungicide Tokat ${ }^{\circledR}$ generated only $5.71 \%$ aseptic explants. Both the combination of Cuprimicin $100^{\circledR}+$
Tokat ${ }^{\circledR}$ and Cuprimicin $500^{\circledR}+$ Prozycar $^{\circledR}$ generated 44.5\% less asepsis than the application of the treatment with Agry-Gent Plus 5000 ${ }^{\circledR}+$ Prozycar $^{\circledR}$ (Figure 1).

The analysis of variance for the type of contaminant indicated that the application of sanitizers to the mother plants had a significant effect on the contamination of explants by fungi and yeasts. The presence of yeasts was greater than that of fungi, although these did not affect the growth of the explants, which grew normally. In most cases, the plants treated with any of the four bactericides in combination with Tokat ${ }^{\circledR}$ showed less yeast contamination (60;60;85,7 and 42,8\%) with respect to the plants treated with Prozycar ${ }^{\circledR}(94,2 ; 80 ; 85,7$ and 48,6\%) (Figure 2), indicating that Tokat ${ }^{\circledR}$ has a better effect on the control of yeast contaminants in philodendron mother plants.

Regarding fungal contamination, treatment of explant donor plants with the fungicide Prozycar ${ }^{\circledR}$ resulted in less fungal contamination $(5,8 ; 17,1 ; 0,0$ and $25,7 \%)$ compared to the application of the fungicide Tokat $^{\circledR}$ where contamination was $50 \%$ higher $(25,7 ; 34,2 ; 14,3$ and $51,4 \%$ ). Based on the results obtained in this study, it can be said that both fungicides control both filamentous fungi and yeasts, with Prozycar ${ }^{\circledR}$ being more effective in controlling fungi and Tokat ${ }^{\circledR}$ in controlling yeasts.

In the overall analysis of the results obtained by the application of sanitizers to mother plants to reduce total contamination, it was observed that according to the type of microorganisms controlled by each sanitizer, the highest

Figure 1 - Asepsis of philodendron explants due to effect of the application of sanitizing products to mother plants. C1+P: Cuprimicin $100^{\circledR}+$ Prozycar $^{\circledR}$, C1+T: Cuprimicin $100^{\circledR}+$ Tokat $^{\mathbb{R}}$, AG + P: Agry-Gent Plus ${ }^{\circledR}+$ Prozycar $^{\mathbb{B}}$, AG + T: Agry-Gent Plus ${ }^{\circledR}+$ Tokat $^{\mathbb{R}}$; C5 + P: Cuprimicin $500^{\circledR}+$ Prozycar $^{\circledR}$, C5+T: Cuprimicin $500^{\circledR}+$ Tokat $^{\circledR}$, AGP+P: Agry Gent Plus $5000^{\circledR}+$ Prozycar $^{\circledR}$, AGP + T: Agry Gent Plus $5000^{\circledR}+$ Tokat $^{\circledR}$

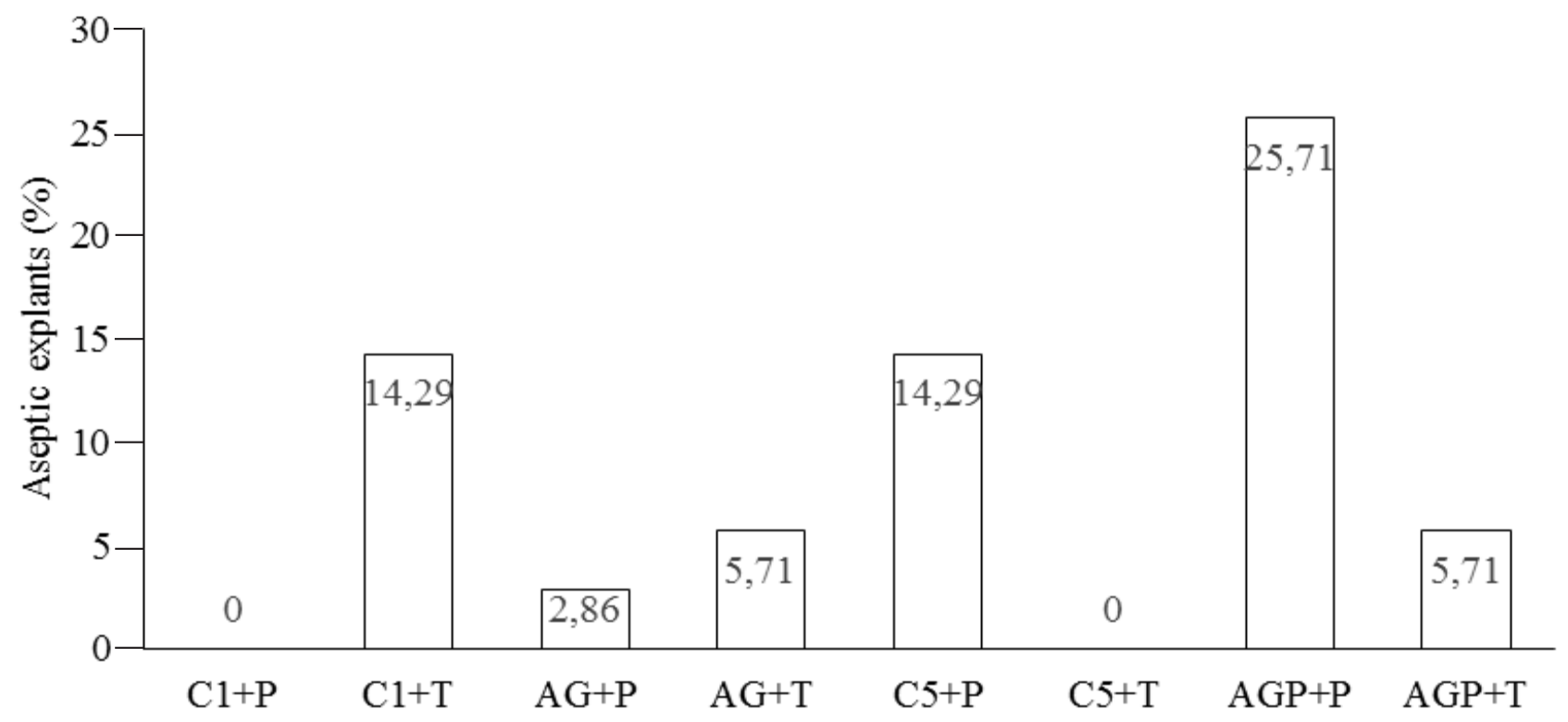


Figure 2 - Type of contaminant of philodendron explants in aseptic culture establishment due to the effect of the application of sanitizing products to mother plants. C1+P: Cuprimicin $100^{\circledR}+$ Prozycar $^{\circledR}, \mathrm{C} 1+\mathrm{T}$ : Cuprimicin $100^{\circledR}+$ Tokat $^{\circledR}$, AG + P: Agry-Gent Plus ${ }^{\circledR}$ + Prozycar $^{\circledR}$, AG + T: Agry-Gent Plus ${ }^{\circledR}+$ Tokat $^{\circledR} ;$ C5 + P: Cuprimicin $500^{\circledR}+$ Prozycar $^{\circledR}$, C5 + T: Cuprimicin $500^{\circledR}+$ Tokat ${ }^{\circledR}$, AGP + P: Agry Gent Plus $5000^{\circledR}+$ Prozycar $^{\circledR}$, AGP+T: Agry Gent Plus $5000^{\circledR}+$ Tokat $^{\circledR}$. Means with the same letters within each contaminant are not statistically different $(\mathrm{LSD}=3.06),(\mathrm{LSD}=2.77)$

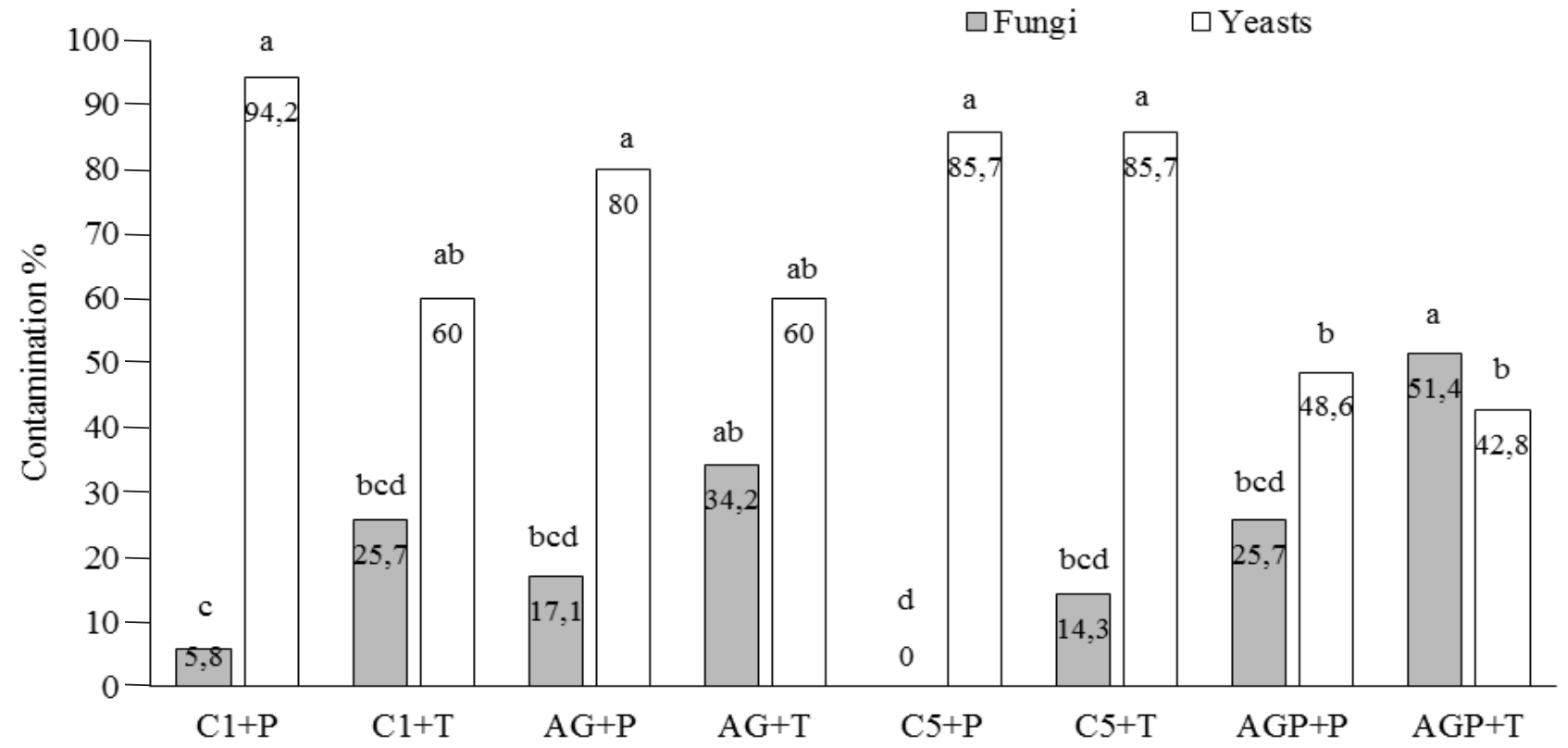

asepsis percentage was achieved by the combination of Agry-Gent Plus 5000 ${ }^{\circledR}$ plus Prozycar ${ }^{\circledR}$ (Figure 1), followed by the treatment of explants with Tokat ${ }^{\circledR}$ and Agry-Gent Plus $5000^{\circledR}$ for 30 min prior to the disinfection process of the explants with ethanol and sodium hypochlorite. The concentration and time of exposure to the sanitizers used in this research during the disinfection process did not negatively affect growth or cause any abnormalities in the already established explant, as has been reported by other authors (AMISSAH et al., 2016).

The pretreatment of mother plants and treatment of explants with fungicides and bactericides prior to the disinfection process was not adequate to establish the in vitro aseptic culture of philodendron, as the maximum asepsis was $25.7 \%$. Chen et al. (2012), observed similar results when establishing the aseptic culture of leaves, petioles and nodal segments of plants of three philodendron cultivars that were sprayed with the fungicides Ridomil $\mathrm{MZ}^{\circledR}$ and Mancozeb $^{\circledR}$, one week prior to the cutting of explants; they disinfected them with $70 \%$ ethanol for one min followed by a $1 \%(\mathrm{v} / \mathrm{v})$ sodium hypochlorite solution for $20 \mathrm{~min}$. In contrast, Blanco and Valverde (2004) obtained 90\% asepsis in in vitro explants of Philodendron sp. by applying the following disinfection procedure: immersion in a solution with Benlate ${ }^{\circledR}$ and Agrimicin ${ }^{\circledR}$ for $30 \mathrm{~min}$, rinsing, application of $95 \%$ ethanol for one min, followed by $3.5 \%$ sodium hypochlorite $(\mathrm{NaOCl})$ for $10 \mathrm{~min}$, two rinsings with sterile water and then applying sodium hypochlorite at $1 \%$ active chlorine for $15 \mathrm{~min}$.

Protocols for disinfecting explants with sanitizing products have been evaluated in other Araceae of ornamental interest. Mariani et al. (2011), established the aseptic culture of Aglaonema sp. by treating explants in immersion for $30 \mathrm{~min}$ in a solution of $\mathrm{Antracol}^{\circledR}$, with $70 \%$ ethanol for two $\min$ and Clorox $^{\circledR}$ at 20 and $50 \%$ for ten min. Bandyopadhyay et al. (2011), obtained 53\% asepsis in the in vitro establishment of Spathyphyllum $s p$. by disinfecting with $1 \%(\mathrm{v} / \mathrm{v}) \mathrm{Teepol}^{\circledR}, 0.2 \%(\mathrm{w} / \mathrm{v})$ Bavistin $^{\circledR}$ and $0.05 \%(\mathrm{v} / \mathrm{v})$ streptomycin sulfate, followed by disinfection with $90 \%$ ethanol for one min and then a solution with $0.1 \%$ mercuric chloride and $0.5 \%$ sodium hypochlorite plus three drops of Tween-20 for $5 \mathrm{~min}$.

According to the results obtained, in order for there to be a good reduction of the pathogenic load through the use of sanitizing products in the treatment of mother plants or directly of explants, it is necessary to choose the appropriate sanitizer and the best time for its application, as well as to know the origin of the explant and the microorganisms associated with it. In addition, plants grown in containers under cover are not directly exposed to contaminants from the soil, air or rain and it is possible to carry out more effective phytosanitary treatments. The 
size of the explant used in this research was suitable, since the shoots had good development; when it is very small it necrotizes easily, while larger ones generate high contamination (BLANCO; VALVERDE, 2004).

Pre-treatment of mother plants and treatment of explants with fungicides and bactericides prior to the disinfection process was considered inadequate to establish in vitro aseptic culture of phyllodendron as only $25.7 \%$ asepsis was obtained, and at least $50 \%$ contaminant-free explants were expected to be obtained. The efficiency of the disinfection method varies depending on the species and the criteria of the researchers, as what someone considers adequate may not be so for the other; in this regard, Chen and Yeh (2007) considered 66.7\% asepsis of Aglaonema 'White Tip' as adequate, while Turina and Bima (2017) indicate that 78\% asepsis and 44\% survival were suitable for in vitro establishment of Olea europea. Given the results obtained in this research, another alternative was sought, of which the following results are presented.

\section{Treatment of mother plants with sanitizers and use of silver nanoparticles (AgNPs)}

The analysis of variance of the results indicated that the addition of AgNPs to the culture medium had a highly significant effect $(\mathrm{P} \leq 0.01)$ in reducing the presence of contaminants in the explants, since there were treatments in which the presence of microorganisms was not observed even after subculturing in the semisolid medium. It is important to note that in this treatment there was no contamination by multicellular fungi, as the contaminated explants had only yeast growth. This indicates the importance of the treatment applied to explant donor plants with specific bactericidal and fungicidal products, as well as the disinfectant agents used during the establishment of the aseptic culture in order to eliminate the contaminants with which the plants coexist during the culture; in this case, the use of AgNPs had a very important effect on the asepsis of philodendron explants.

The asepsis of the explants established in vitro ranged from 0 to $80 \%$ depending on the combinations of sanitizing products applied to the mother plants. As in the in vitro establishment of explants described in the previous experiment, the mother plant treatment consisting of $2 \mathrm{~g} \mathrm{~L}^{-1}$ of the bactericide Agry-Gent Plus $5000^{\circledR}$ plus $2 \mathrm{~g} \mathrm{~L}^{-1}$ of the fungicide Prozycar ${ }^{\circledR}$ generated the highest explant asepsis, which in this case was $100 \%$. As already mentioned, this effect is attributed to the synergy generated between the two sanitizing products to eliminate fungi and bacteria, as well as to the antimicrobial effect of the AgNPs. The treatment composed of Agry-Gent Plus ${ }^{\circledR}$ and Prozycar ${ }^{\circledR}$ generated $80 \%$ explant asepsis; this treatment is also considered adequate to initiate in vitro culture of philodendron, as it exceeds the $50 \%$ minimum expected. The treatments using Cuprimicin $100^{\circledR}+$ Prozycar $^{\circledR}$, Cuprimicin $500^{\circledR}+$ Tokat ${ }^{\circledR}$ and Agry-Gent Plus $5000^{\circledR}+$ Tokat $^{\circledR}$ generated $40 \%$ asepsis; with the other three treatments there was yeast contamination in all explants (Table 2).

The above indicates that the use of AgNPs significantly helped improve asepsis since it was possible to have 40,80 and $100 \%$ of explants free of microorganisms, while in the previous experiment where this germicide was not used, the highest asepsis was $25.7 \%$. However, asepsis also depended to a large extent on the bactericides and fungicides with which the mother plants were treated during their culture.

According to Amissah et al. (2016), contaminated explants die because the contaminants utilize the nutrientrich medium for growth and eventually out-compete the explants for nutrients and oxygen, in addition to secreting phytotoxins that have harmful effects (CAPÓ, 2000; MNG'OMBA et al., 2012). In this research, the yeasts that were observed growing together with the explants did not affect, to the naked eye, the growth of the explants since they grew and formed shoots like the non-contaminated ones; however, in in vitro culture, there must be total asepsis in the explants because yeast growth can be confused with the incidence of bacteria.

The results of the in vitro establishment of philodendron in this work partially agree with those reported by some authors on the positive effect of the use of AgNPs in the in vitro culture of plant tissues. It was not possible to have total asepsis in all treatments, possibly because in this research the AgNPs were applied only for seven days and not during the whole culture period as reported in the consulted research.

Spinoso-Castillo et al. (2017) report the use of AgNPs as an antimicrobial agent and their hormetic response in vanilla seedlings in a temporary immersion system and indicate that bacterial contamination was reduced to zero with 50, 100 and $200 \mathrm{mg} \mathrm{L}^{-1}$ of AgNPs and growth stimulation occurred with 25 and $50 \mathrm{mg} \mathrm{L}^{-1}$ of NPsAg, while significant growth inhibition was observed at 100 and $200 \mathrm{mg} \mathrm{L}^{-1}$ of AgNPs, so $50 \mathrm{mg}$ of AgNPs per liter of culture medium was the most suitable to reduce bacterial contamination and induce a hormetic response; not using this disinfectant generated $16.6 \%$ contamination. Studies by Kumar et al. (2014), report that the use of AgNPs during seed germination of three Fabaceae species inhibited microbial contamination, as seeds not treated with AgNPs showed rich bacterial and fungal growth.

The amount of AgNPs required to achieve asepsis varies depending on the species and the culture conditions of the explant donor plants. The modification of the culture medium with the addition of substances with bactericidal or fungicidal effect 
Table 2 - Effect of the application of sanitizing products to mother plants and the use of AgNPs in the aseptic culture of philodendron

\begin{tabular}{|c|c|c|}
\hline Treatment Bactericide + Fungicide & Aseptic explants (\%) & Yeast contamination $(\%)$ \\
\hline 1: Cuprimicin 100® + Prozycar ${ }^{\circledR}$ & $40 \mathrm{bc}$ & $60 \mathrm{ab}$ \\
\hline 2: Cuprimicin $100 \AA+$ Tokat $\AA$ & $0 \mathrm{c}$ & $100 \mathrm{a}$ \\
\hline 3: Agry-Gent Plus ${ }^{\circledR}+$ Prozycar ${ }^{\circledR}$ & $80 \mathrm{ab}$ & $20 \mathrm{bc}$ \\
\hline 4: Agry-Gent Plus ${ }^{\circledR}+$ Tokat ${ }^{\circledR}$ & $0 \mathrm{c}$ & $100 \mathrm{a}$ \\
\hline 5: Cuprimicin $500 \AA+\operatorname{Prozycar} \AA$ & $0 \mathrm{c}$ & $100 \mathrm{a}$ \\
\hline 6: Cuprimicin $500 \AA+$ Tokat ${ }^{\circledR}$ & $40 \mathrm{bc}$ & $60 \mathrm{ab}$ \\
\hline 7: Agry Gent Plus 5000® + Prozycar ${ }^{\circledR}$ & $100 \mathrm{a}$ & $0 \mathrm{c}$ \\
\hline 8: Agry Gent Plus 5000® + Tokat ${ }^{\circledR}$ & $40 \mathrm{bc}$ & $60 \mathrm{ab}$ \\
\hline $\mathrm{LSD}(\mathrm{P} \leq 0,05)$ & 4.45 & 4.45 \\
\hline
\end{tabular}

LSD: least significant difference. Means with the same letters in a column are not statistically different

generates good results in terms of explant asepsis; however, the presence of these compounds in the culture medium can cause toxicity, malformations, significant growth inhibition and even explant death (ABREU et al., 2016; AMISSAH et al., 2016). According to the results obtained and the findings reported by Kumar et al. (2014); Spinoso-Castillo et al. (2017), the use of AgNPs in the in vitro culture of plant tissues exerts an antimicrobial and growth stimulating effect, without posing any harmful risks.

\section{Identification of contaminants}

The fungal agents observed invading philodendron explants in the first experiment reported in this research were Aspergillus sp. and Penicillium sp. (Figura 3). These are filamentous fungi important for their adaptability to diverse habitats such as soils, water, organic matter, plant tissues, and fresh and dry postharvest plant products. In addition, these microorganisms have been reported as frequent contaminants in in vitro tissue culture and have been called vitro pathogens (CAPÓ, 2000; PEDROZAMANRIQUE; MONTES-VILLEGAS, 2008), whose growth is undesirable because they completely cover the explants and cause their death.

As a result of the sowing of the pure culture initially identified as bacterial in PDA, PDA with lactic acid and EMB media, at 24, 48 and 72 hours, it was observed that all of them formed colonies with similar morphology, namely a dull whitish color, a creamy appearance and mucous consistency, identical to the initial pure culture. The inoculated potato slices did not show any difference with the control (uninoculated); only the oxidation of the tissue where the scratching was carried out was observed, even after seven days of inoculation. The interpretation of the results indicates that the contaminant was yeast. These results agree with those of Guevara-Vázquez et al. (2009), who obtained colonies with similar characteristics in PDA medium when isolating and identifying yeasts associated with huitlacoche ( $U$. maydis) in corn cobs that were observed exerting antagonism on the phytopathogen and identified as Pichia sp. and Candida sp.

In addition to being classified as main vitro pathogens, yeasts, together with fungi and bacteria, inhabit different niches such as soil, water, closed and open environments, roots, stems, leaves, flowers, fruits, and insects, in addition to which some are directly related to humans; this amply explains the high probability of the presence of yeasts in in vitro cultures, mainly when the aseptic culture is established (CAPÓ, 2000; MNG'OMBA et al., 2012). The presence of yeasts in the culture media did not affect the growth of the philodendron explants, as vigorous growth with shoot formation was observed.

The filamentous fungi did not damage the plant tissue directly, but by being present inside the culture vessel they completely invaded the culture medium and explants. Some research reports the development of diseases in plants of the family Araceae at different growth stages whose causal agents have been mainly bacteria (MOYA-HERNÁNDEZ; RODRÍGUEZMEJÍA; ESPINOSA-MENDOZA, 2015; RAMÍREZROJAS et al., 2016; SÁNCHEZ et al., 2015), which may be the explanation for the frequency with which they are found growing in vitro; however, in this research the bacteria were not contaminants, probably due to the efficiency of the application of bactericides to the explant donor mother plants. 
Figure 3 - A1: Aspergillus sp. on PDA medium, A2: hyphae and conidiophores with radially-shaped head characteristic of Aspergillus sp. (40X), B1: Penicillium sp. on PDA medium, B2: brush-shaped conidiophores characteristic of Penicillium sp. 40X

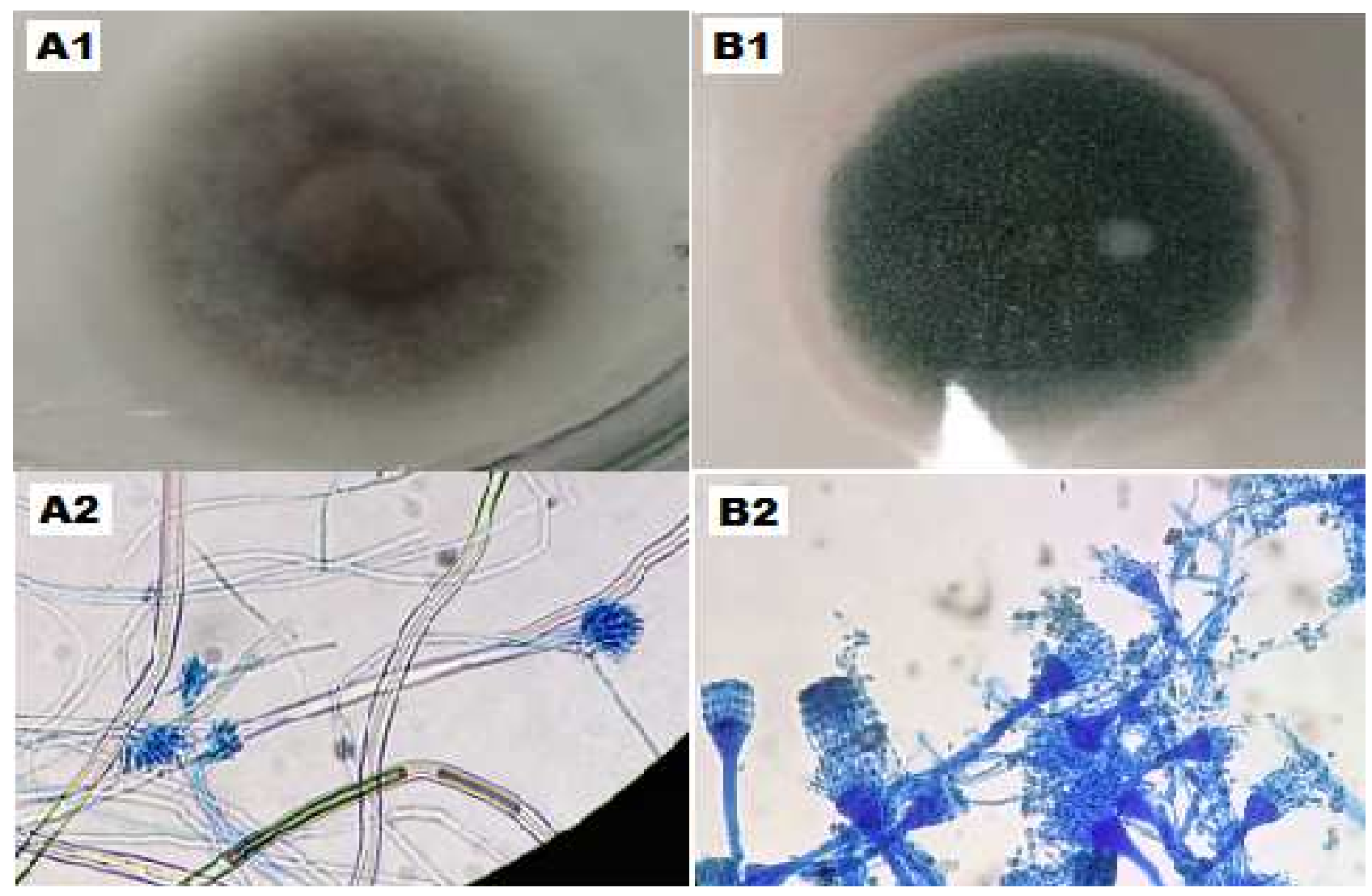

\section{CONCLUSIONS}

1. The application of bactericides and fungicides as a pretreatment of mother plants was not enough to obtain a $100 \%$ aseptic in vitro culture of philodendron; there was contamination by Aspergillus sp, Penicillium sp. and yeasts. However, they totally controlled the incidence of bacteria;

2. The treatment of philodendron mother plants with Agry Gent Plus $5000^{\circledR}+$ Prozycar $^{\circledR}$ and the addition of AgNPs to the culture medium for seven days allowed obtaining totally contaminant-free explants; it allowed generating a protocol for the establishment of the aseptic culture of this species. The use of AgNPs prevented the contamination of philodendron explants with fungi.

\section{REFERENCES}

ABDI, G.; SALEHI, H.; KHOSH-KHUI, M. Nanosilver: a novel nanomaterial for removal of bacterial contaminants in valerian
(Valeriana officinalis L.) tissue culture. Acta Physiologiae Plantarum, v. 30, n. 5, p. 709-714, 2008.

ABREU, E. et al. Efecto de antibióticos en la propagación in vitro de Agave fourcroydes Lem. Biotecnología Vegetal, v. 16, n. 1, p. 31-36, 2016.

ACEBEY, A.; KRÖMER, T. Diversidad y distribución de Araceae de la Reserva de la Biosfera de los Tuxtlas Veracruz, México. Revista Mexicana de Biodiversidad, v. 79, n. 2, p. 465-471, 2008.

AKIKO. 2020. Disponible en: https://akiko.com.mx/productos/ plantulas/. Acceso en: 23 sept. 2020.

AMISSAH, S. et al. In vitro control of microbial contamination of sweet potatoes cultured with nodal explants. Annual Research \& Review in Biology, v. 9, n. 3, p. 1-8, 2016.

AZOFEIFA-BOLAÑOS, J. B. et al. Efecto de la desinfección de segmentos nodales sobre el rendimiento morfogenético de vitroplantas de Vanilla planifolia Andrews. Agronomía Mesoamericana, v. 30, n. 1, p. 17, 2019.

BANDYOPADHYAY, T. K. et al. An efficient micropropagation protocol to control abnormality in longterm shoot cultures of Spathiphyllum floribundum (L.) 
'Petite'. Floriculture and Ornamental Biotechnology, v. 5, n. 1, p. 57-63, 2011.

BLANCO, M.; VALVERDE, R. Micropropagación de Philodendron sp. (Posiblemente P. corcovadense). Agronomia Costarricense, v. 28, n. 1, p. 39-46, 2004.

BOYCE, P. C.; CROAT, T. B. The Überlist of Araceae: totals for published and estimated number of species in aroid genera. 2014. Disponible en: http://www.aroid.org/genera/140601uberlist.pdf. Acceso en: 20 nov. 2017.

CAPÓ, Y. A. Control y prevención de la contaminación microbiana en la micropropagación de plantas. Revista CENIC Ciencias Biológicas, v. 31, n. 2, p. 87-91, 2000.

CHEN, F. C. et al. Micropropagation of self-heading Philodendron via direct shoot regeneration. Scientia Horticulturae, v. 141, p. 23-29, 2012.

CHEN, W. L.; YEH, D. M. Elimination of in vitro contamination, shoot multiplication, and ex vitro rooting of Aglaonema. HortScience, v. 42, n. 3, p. 629-632, 2007.

FLORAMUNDO.2020.Disponibleen:https://vivero.floramundo. com.mx/index.php?route=product/product\&product $\mathrm{id}=348$. Acceso en: 23 sept. 2020.

GUEVARA-VÁZQUEZ, E. et al. Identificación de levaduras asociadas al huitlacoche. Revista Chapingo Serie Horticultura, v. 15, n. 3 , p. $225-230,2009$.

KUMAR, S. S. et al. Biogenic silver nanoparticles synthesized with mediation by Euphorbia hirta enhance seed germination and eliminate microbial contamination. World Journal of Pharmacy and Pharmaceutical Sciences, v. 3, n. 5, p. 784-794, 2014.

MARIANI, T. S. et al. Micro propagation of Aglaonema using axillary shoot explants. International Journal of Basic \& Applied Sciences, v. 11, n. 1, p. 46-53, 2011.

McCONNELL, D. B. et al. Cultural guidelines for commercial production of interiorscape Philodendron. University of Florida. 2003. Disponible en: http://edis.ifas. ufl.edu. Acceso en: 15 enero 2018.

MNG 'OMBA, S. A. et al. Efficacy and utilization of fungicides and other antibiotics for aseptic plant cultures. In: THAJUDDIN, N.; ANNAMALAI, P. S. Fungicides for plant and animal diseases. Rijeka: InTech, 2012. cap. 12, p. 245-254.

MORADPOUR, M.; AZIZ, M. A.; ABDULLAH, S. N. A. Establishment of in vitro culture of rubber (Hevea brasiliensis) from field-derived explants: effective role of silver nanoparticles in reducing contamination and browning. Journal of Nanomed \& Nanotechnology, v. 7, n. 3, p. 7, 2016.

MOYA-HERNÁNDEZ, S. L.; RODRÍGUEZ-MEJÍA, M. L.; ESPINOSA-MENDOZA, M. Xanthomonas campestris pv. campestris causante de manchas foliares del filodendro (Philodendron scadens subsp. oxycardium) en Cuautla, Morelos, México. Revista Mexicana de Ciencias Agrícolas, v. 6, n. 2, p. 391-397, 2015.

MURASHIGE, T.; SKOOG, F. A revised medium for rapid growth and bioassays with tobacco tissue cultures. Physiologia Plantarum, v. 15, p. 473-497, 1962.

PEDROZA-MANRIQUE, J. A.; MONTES-VILLEGAS, M. V. Micropropagación de Hypericum goyanesii, una especie en vía de extinción. Revista Científica, n. 10, p. 109-118, 2008.

RAMÍREZ-ROJAS, S. et al. Identificación molecular de bacterias asociadas a plantas ornamentales producidas in vitro. Revista Mexicana de Fitopatología, v. 34, n. 2, p. 173-183, 2016.

ROUT, G. R.; MOHAPATRA, A.; JAIN, S. M. Tissue culture of ornamental pot plant: a critical review on present scenario and future prospects. Biotechnology Advances, v. 24, n. 6, p. 531-560, 2006.

SÁNCHEZ, Y. G. et al. Incidência de contaminantes microbianos na propagação in vitro de Xathosoma spp. clon 'INIVIT MX2007' e Colocasia esculenta (L.) Schott. clone 'INIVIT MC2012'. Biotecnología Vegetal, v. 15, n. 3, p. 157-161, 2015.

SPINOSO-CASTILLO, J. L. et al. Antimicrobial and hormetic effects of silver nanoparticles on in vitro regeneration of vanilla (Vanilla planifolia Jacks. Ex Andrews) using a temporary immersion system. Plant Cell, Tissue Organ and Culture, v. 129, n. 2, p. 195-207, 2017.

STEINER, A. A. The universal nutrient solution. In: INTERNATIONAL CONGRESS ON SOILLESS CULTURE, 6 , 1984, Lunteren. Proceedings [...]. Lunteren: ISOSC, 1984. p. 633-649.

TURINA, C. A.; BIMA, P. Establecimiento in vitro de cuatro variedades de olivo cultivadas a campo (Olea europea L.). Agriscientia, v. 34, n. 2, p. 59-68, 2017.

VILLAMIZAR-GALLARDO, R.; CRUZ, J. F. O.; ORTÍZRODRÍGUEZ, O. O. Fungicidal effect of silver nanoparticles on toxigenic fungi in cocoa. Pesquisa Agropecuaria Brasileira, v. 51, n. 12, p. 1929-1936, 2016. 